\title{
A comparison of the organic and conventional livestock farming systems of Avalon Farming in West Otago
}

\author{
A. and S. RICHARDSON \\ Heriot, RD 2 Tapanui, West Otago \\ avalon@esi.co.nz
}

\section{Introduction}

Organic farming in New Zealand is not considered a mainstream option for farmers. This paper compares organic and conventional farms running side by side at Avalon Farming and details why Avalon Farming is expanding its organic area.

Included in the paper are details of the conversion to organic farming and its success. Topics include:

1. Challenges of converting from a conventional to an organic system.

2. Comparing conventional and organic production and the financial returns.

3. Marketing options for organic farmers in New Zealand including the growth of farmers markets.

\section{Approach \\ Conversion to Organics}

There is a 2 year conversion period for AgriQuality standards. Conversion began in 1997 when the first step was to stop applying chemical fertilisers on 35 hectares. In 1998, an extra 90 hectares was added and the stock were farmed organically on this area. The full conversion timetable is outlined in Table 1. In February 2006 Avalon Farming gained organic status on the remaining 190 hectares, giving the whole farm of 500 hectares organic status.

Reactive Phosphate Rock (RPR) at $125 \mathrm{~kg} / \mathrm{ha}$ plus elemental sulphur (ES) at $30 \mathrm{~kg} / \mathrm{ha}$ was applied in 1997 , followed by Foliafeeds Simply Organic foliar mix the next year. Probitas, a natural fertiliser which can be used

Table 1 Conversion timetable detailing the area of land in each part of the certification process (total farm area $=500 \mathrm{ha})$

\begin{tabular}{cccc}
\hline \multicolumn{4}{c}{$\begin{array}{c}\text { Area of land in each part of the certification process (ha) } \\
\text { Organic (year 3) }\end{array}$} \\
\hline 1997 & Conversion (year 1) & & \\
1998 & 35 & 35 & 35 \\
1999 & 90 & 90 & 125 \\
2000 & 76 & 76 & 201 \\
2001 & 107 & 107 & 308 \\
2002 & & & \\
2003 & 192 & 192 & 500 \\
2004 & & & \\
2005 & & & \\
2006 & & & \\
\hline
\end{tabular}

Table 2 Fertiliser applied to the organic farming unit

\begin{tabular}{|c|c|c|c|}
\hline Year & Products & Rate & Area (ha) \\
\hline 1997 & $\begin{array}{l}\text { Reactive Phosphate Rock (RPR) } \\
\text { Elemental Sulphur (ES) }\end{array}$ & $\begin{array}{c}125 \mathrm{~kg} / \mathrm{ha} \\
30 \mathrm{~kg} / \mathrm{ha}\end{array}$ & 35 \\
\hline 1998 & Foliafeed Simply Organic & $15 \mathrm{~L} / \mathrm{ha}$ & 125 \\
\hline 1999 & $\begin{array}{l}\text { RRP } \\
\text { ES }\end{array}$ & $\begin{array}{c}125 \mathrm{~kg} / \mathrm{ha} \\
30 \mathrm{~kg}\end{array}$ & 201 \\
\hline 2000 & Foliafeed Simply Organic & $15 \mathrm{~L} / \mathrm{ha}$ & 220 \\
\hline 2001 & Lime and Minerals & $125 \mathrm{~kg} / \mathrm{ha}$ & 220 \\
\hline 2002 & $\begin{array}{l}\text { RRP } \\
\text { ES }\end{array}$ & $\begin{array}{l}125 \mathrm{~kg} / \mathrm{ha} \\
30 \mathrm{~kg} / \mathrm{ha}\end{array}$ & 259 \\
\hline 2003 & $\begin{array}{l}\text { Probitas } \\
\text { Lime }\end{array}$ & $\begin{array}{c}150 \mathrm{~kg} / \mathrm{ha} \\
2.5 \text { tonne/ha }\end{array}$ & 236 \\
\hline 2004 & Drought conditions & 0 & - \\
\hline 2005 & $\begin{array}{l}\text { Probitas } \\
\text { Lime }\end{array}$ & $\begin{array}{l}150 \mathrm{~kg} / \mathrm{ha} \\
1 \text { tonne/ha }\end{array}$ & 240 \\
\hline & Lime and minerals & $125 \mathrm{~kg} / \mathrm{ha}$ & 220 \\
\hline 2006 & Lime and minerals & $125 \mathrm{~kg} / \mathrm{ha}$ & 460 \\
\hline
\end{tabular}


Table 3 Conventional (Marks) and Organic (Parkhill) pasture mixes sown

\begin{tabular}{lcc}
\hline & \multicolumn{2}{c}{ Sowing rate $(\mathrm{kg} / \mathrm{ha})$} \\
& $\begin{array}{c}\text { Marks sown } \\
\text { in 1988 }\end{array}$ & $\begin{array}{c}\text { Parkhill sown } \\
\text { in 2004 }\end{array}$ \\
\hline $\begin{array}{lc}\text { Banquet LE ryegrass } \\
\text { Nui ryegrass }\end{array}$ & 25 & 15 \\
$\begin{array}{l}\text { Demand white clover } \\
\text { Sustain white clover }\end{array}$ & & 2 \\
Huia white clover & 4 & 3 \\
G27 red clover & & 3 \\
Colenso red clover & & 2 \\
Charlton Timothy & & 1 \\
Tonic Plantain & & 1 \\
Grouse Chicory & & .5 \\
Maru Phlaris & & .5 \\
Yarrow & & 29 \\
\hline Total & 29 & \\
\hline
\end{tabular}

organically, has also been added to the programme. Fertiliser use is outlined in Table 2. Probitas is a lime based soil conditioner developed by Ewan Campbell, a Waihi sheep and beef farmer. It has amounts of silica, sea based minerals and paramagnetic rock. We have measured up to 82 worms per spade full since we started using this product, higher Omega 3 levels in our lamb and beef and a longer shelf life for our organic lamb and beef sold under Avalon Organic.

The stock had been selected for resistance to internal parasites for 10 years, so there was not a significant drop in performance. The initial results were promising and more land was converted as soil biology and problem weeds such as gorse were controlled.

\section{Pasture composition}

Pastures are grazed on rotation all year apart from lambing. High endophyte Nui ryegrass and Huia white clover were the traditional mixes until the mid 1990s when low endophyte ryegrass was used. Under organics, a herbal ley such as that sown in the Parkhill paddock (Table 3 ) is being used successfully. We are also finding more timothy and clover coming back into our pastures.

\section{Results}

The following results compare the soil fertility and herbage growth rates on two organic areas. A

comparison of the animal performance between organic and conventional is also detailed. Finally a financial analysis of both systems based on sheep and beef operations but excluding the stud sheep operation is given.

\section{Herbage growth rates}

Two organic sites were established in October 2005 and they have been measured using the Meat and Wool NZ Pasture Plan monitoring protocol. Three plots per site were used with a residual dry matter of approximately 1200,1500 and $2000 \mathrm{~kg} / \mathrm{DM}$. Ten measurements per plot were recorded using a Speedrite Grassmaster digital probe.

The following are the pasture growth trial parameters.

- Two sites

- Parkhill altitude $400 \mathrm{~m}$

- Marks altitude $270 \mathrm{~m}$

- Three plots per site $\quad 0.36 \mathrm{~m}^{2}(600 \mathrm{~mm}$ x 600

- Starting cover $\mathrm{mm})$ metal cages

- Parkhill

- Marks

- Growth interval

- Cutting method

- Age of pasture

$680 \mathrm{~kg} \mathrm{DM} / \mathrm{ha}$ $960 \mathrm{~kg} \mathrm{DM} / \mathrm{ha}$

15 days

lawnmower with clippings removed

- Parkhill 1 year

- Marks 18 years

The average pasture production on the organic pasture mix sown in the Parkhill paddock was $13,320 \mathrm{~kg} \mathrm{DM} /$ ha over the 200 days measured, while the conventional mix in the Marks paddock only produced $10,110 \mathrm{~kg}$ $\mathrm{DM} / \mathrm{ha}$ (Table 4). This relates to growth rates of 66 and $51 \mathrm{~kg} \mathrm{DM} / \mathrm{ha} / \mathrm{d}$ on the new organic and old conventional pasture mixes respectively. The newer sowing in the Parkhill paddock also produced more when the residual pasture mass was increased. This would be expected due to the greater number of herbs and clovers that are included. The pasture growth patterns were similar at most times though the Marks paddock did produce more in the late autumn than the Parkhill paddock, probably as a result of the difference in altitude and relative contribution of herbs and clovers. These results compare well to the pasture production measured by the same technique on a conventional farm close by (Table 5).

Table 4 Total and average growth rates of the organic and conventional pasture mixes during the first 200 days (from $21 / 10 / 05$ to $9 / 5 / 06$ ) of monitoring.

\begin{tabular}{lccccccc}
\hline Pasture mix & \multicolumn{4}{c}{ Organic (Parkhill) } & \multicolumn{4}{c}{ Conventional (Marks) } \\
\cline { 2 - 8 } & 1200 & 1500 & 2000 & 1200 & 1500 & 2000 \\
\hline Total $(\mathrm{kg} \mathrm{DM} / \mathrm{ha})$ & 12807 & 13052 & 14086 & 10831 & 9761 & 9746 \\
Daily growth rate $(\mathrm{kg} \mathrm{DM} / \mathrm{ha})$ & 64 & 65 & 70 & 54 & 49 & 49 \\
\hline
\end{tabular}


Table 5 Annual yields (kg DM/ha/annum) from Meat and Wool Innovations Pasture Plan Pasture Growth trials undertaken by Mr Donald Martin at "Mt Allen" 18 kilometres from Heriot (Period 15/06/02 - 15/06/05)

\begin{tabular}{lcc}
\hline Period & $\begin{array}{c}\text { New pasture } \\
\text { south facing }\end{array}$ & $\begin{array}{c}5 \text {-year pasture } \\
\text { north facing }\end{array}$ \\
\hline $15 / 6 / 02-1 / 6 / 03$ & 14952 & 11000 \\
$1 / 7 / 03-15 / 6 / 04$ & 8545 & 11359 \\
$1 / 7 / 04-15 / 6 / 05$ & 10771 & 13603 \\
\hline
\end{tabular}

\section{Soil fertility}

The soil fertility recommendations are based on reports completed by the Albrecht Base Saturation method, which measures base saturation of the soil cations. Two paddocks are detailed with three tests in 1998, 2002, 2005 , as well as results from an organic dairy farm near Riverton, Southland (Table 6).

Mr Mike Thompson from Riverton, Southland is a dairy farmer, who has used Probitas (150 kg Probitas plus 2.5 tonnes lime per annum) and fish fertiliser (20 litres BioSeal Fish Fertiliser) over the past 2 years. One of his new grass paddocks was also tested by Ballance Agri Nutrients and their figures are in brackets in the last column in Table 6 to allow a comparison of the Albrecht versus traditional soil tests.

The whole farm has now had one application of Probitas plus lime. The exceptions are paddocks that have been cut for hay or silage which receive a second application of Probitas and lime. Young grass paddocks receive $250 \mathrm{~kg}$ RPR along with Probitas and lime. Our calcium, magnesium base saturation ratios are not high enough and a magnesium source will be included in our fertiliser program for 2006/07 to boost our magnesium levels. We are finding that we still need to apply trace elements, based on annual herbage testing, to maintain plant and animal performance.

\section{Stock performance}

Scanning and lambing data are presented in Table 7. The 2006 year only has the organic system as the entire farm is now accredited.

The 4-year average lambing percentage for the conventional system was $125 \%$ while it was $119 \%$ in the organic system. This was mostly due to slightly lower ewe liveweights at mating under the organic system compared with the conventional, as the fertility index was similar in each year. Part of this effect was also due

Table 6 Soil test results from a paddock converted in 1997 (Bridge) and in 1998 (Marks) and a dairy farm near Riverton, Southland (Standard NZ MAF soil test results in brackets where applicable).

\begin{tabular}{|c|c|c|c|c|c|c|c|}
\hline Date Sampled (mm/yy) & $10 / 98$ & $\begin{array}{c}\text { - Bridge } \\
01 / 02\end{array}$ & $111 / 05$ & $10 / 98$ & $\begin{array}{r}\text { - Marks } \\
01 / 02\end{array}$ & $11 / 05$ & $\begin{array}{c}\text { Riverton } \\
7 / 06\end{array}$ \\
\hline CEC * & 13.64 & 15.2 & 14.43 & 15.99 & 18.47 & 13.97 & 14.23 \\
\hline $\mathrm{pH}$ & 6.0 & 5.8 & 5.9 & 5.7 & 5.4 & 6.1 & $5.4(6.0)$ \\
\hline Organic Matter & 4.5 & 5.2 & 4.8 & 4.3 & 5.7 & 5.6 & 10.04 \\
\hline $\mathrm{N} \mathrm{kg/ha}$ & 89 & 95 & 92 & 86 & 98 & 97 & \\
\hline Sulphate ppm & 10 & 16 & 13 & 9 & 18 & 15 & $22(13)$ \\
\hline Bray Phosphate ppm & 49 & 55 & 61 & 47 & 43 & 37 & $46(14)$ \\
\hline Ca kg/ha (MAF units) & $1298(9)$ & $1321(9)$ & $1062(9)$ & $1130(8)$ & $1193(8)$ & $1149(10)$ & $3295(13)$ \\
\hline Mg kg/ha (MAF units) & $135(18)$ & $134(18)$ & $121(28)$ & $166(22)$ & $145(20)$ & $87(20)$ & $437(35)$ \\
\hline K kg/ha (MAF units) & $157(9)$ & $235(13)$ & $128(9)$ & $174(10)$ & $182(10)$ & $124(9)$ & $195(12)$ \\
\hline $\mathrm{Na} \mathrm{kg/ha} \mathrm{(MAF} \mathrm{units)}$ & $48(9)$ & $57(11)$ & $46(14)$ & $46(8)$ & $50(9)$ & $39(12)$ & $61(13)$ \\
\hline \multicolumn{8}{|l|}{ Base Saturation \% } \\
\hline $\mathrm{Ca}$ & 62.8 & 56.4 & 59.3 & 51.5 & 45.8 & 67.1 & 51.7 \\
\hline $\mathrm{Mg}$ & 10.9 & 9.5 & 11.3 & 12.6 & 9.3 & 8.5 & 11.42 \\
\hline $\mathrm{K}$ & 3.9 & 5.1 & 3.7 & 4.1 & 3.6 & 3.7 & 1.1 \\
\hline $\mathrm{Na}$ & 2.0 & 2.1 & 2.2 & 1.8 & 1.7 & 2.0 & 1.92 \\
\hline Other Bases & 5.4 & 5.8 & 5.6 & 6.0 & 6.6 & 5.2 & 0.86 \\
\hline Hydrogen & 15 & 21 & 18 & 24.0 & 33.0 & 13.5 & 3.3 \\
\hline \multicolumn{8}{|l|}{ Trace Elements (ppm) } \\
\hline B & 0.7 & 0.73 & 1.18 & 0.4 & 0.86 & 1.01 & \\
\hline $\mathrm{Fe}$ & 889 & 899 & 1662 & 883 & 909 & 1680 & \\
\hline $\mathrm{Mn}$ & 47 & 40 & 38 & 55 & 43 & 44 & \\
\hline $\mathrm{Cu}$ & 0.8 & 1.1 & 1.0 & 1.0 & 1.1 & 1.2 & \\
\hline $\mathrm{Zn}$ & 2.8 & 3.1 & 5.3 & 3.5 & 3.3 & 3.8 & \\
\hline Co & 1.67 & 1 & 3.68 & 1.32 & 0.99 & 3.82 & \\
\hline Mo & 0.92 & 1.56 & 0.2 & 0.92 & 1.52 & 0.2 & \\
\hline
\end{tabular}

* Cation Exchange Capacity 
Table 7 The sheep reproductive data for conventional and organic farming systems at Avalon Farming

\begin{tabular}{lcccccccccc}
\hline & \multicolumn{2}{c}{2002} & \multicolumn{2}{c}{2003} & \multicolumn{2}{c}{2004} & \multicolumn{2}{c}{2005} \\
& ${ }^{2} \mathrm{C}$ & ${ }^{2} \mathrm{O}$ & $\mathrm{C}$ & $\mathrm{O}$ & $\mathrm{C}$ & $\mathrm{O}$ & $\mathrm{C}$ & $\mathrm{O}$ & $\mathrm{O}$ \\
\hline Scanning \% & 150 & 151 & 150 & 140 & 170 & 160 & 157 & 155 & 160 \\
Ewe weight at mating (kg) & 55.5 & 55.7 & 59 & 53.6 & 62.9 & 59.2 & 58.9 & 58.4 & 59.2 \\
Fertility Index (scanning \%/LWT) & 2.7 & 2.7 & 2.5 & 2.5 & 2.7 & 2.7 & 2.6 & 2.6 & 2.7 \\
Drys (\%) & 3.7 & 4.2 & 2.6 & 6.7 & 2.2 & 3.1 & 2.8 & 3.8 & 2.9 \\
Lambing (\%) & 127 & 119 & 116 & 110 & 134 & 127 & 124 & 121 \\
\hline
\end{tabular}

${ }^{1} \mathrm{C}=$ conventional

${ }^{2} \mathrm{O}=$ organic

Table 8 Lamb carcass weights and prices since 2003

\begin{tabular}{lcccc}
\hline & \multicolumn{2}{c}{ Carcass Weight $(\mathrm{kg})$} & \multicolumn{2}{c}{ Prices $(\$)$} \\
& C & O & C & O \\
\hline 2003 / 04 drought & stores & 14.6 & 59.30 & 82.40 \\
2004 / 05 & 15.9 & 14.8 & 57.60 & 75.88 \\
2005 / 06 all organic & & 15.0 & & 69.61 \\
\hline
\end{tabular}

Table 9 The biological parameters and product prices used to estimate the financial returns from conventional and organic farming systems at Avalon Farming.

\begin{tabular}{lcc}
\hline & Conventional & Organic \\
\hline Lambing percentage (4-year average) & 125 & 119 \\
Lamb carcass weight (3-year average) & 15.9 & 14.8 \\
Number of lambs sold & 3450 & 3300 \\
Wool kg/sheep su & 4.5 & 4.2 \\
Total wool sold (kg) & 20880 & 19490 \\
Beef carcass weight (kg) & 280 & 280 \\
Total beef sold (kg) & 14000 & 14000 \\
Stocking Rate per hectare & 11.0 & 11.0 \\
Stock units (5260 stock numbers) & 5260 & 5260 \\
Ewes (3800) & 3800 & 3800 \\
Hoggets (1200) & 840 & 840 \\
Rams (40) & 40 & 40 \\
2 yr cattle (50) & 300 & 300 \\
1 yr cattle (70) & 280 & 280 \\
Sheep : Cattle ratio & $90: 10$ & $90: 10$ \\
Effective area & 470 ha & 470 ha \\
Lamb sales & $100 \%$ prime & $70 \%$ prime \\
Lamb price (\$/hd) & $\$ 50$ & $30 \%$ store \\
Beef price $(\$ / \mathrm{kg})$ & $\$ 2.90$ & $\$ 70$ \\
Wool price $(\$ / \mathrm{kg})$ & $\$ 2.68$ & $\$ 43$ \\
\hline
\end{tabular}

to a small increase in the percent dry ewes in the organic system (average $2.8 \mathrm{vs} 4.4 \%$ for conventional and organic systems respectively).

\section{Lamb carcass weights and prices}

The lamb carcass weights from the organic system were $1 \mathrm{~kg}$ lighter than those in the conventional system in the 2004/05 season when the two groups were comparable, but the organic lambs still attracted a premium of over $\$ 12 /$ head (Table 8 ).

\section{Financial analysis}

In order to make a fair comparison, the stud sheep operation has been removed from this financial analysis and a fattening system has been calculated. Because the whole property was farmed organically from February 2006, some of the conventional expenses are based on Ibbotson Cooney - Chartered Accountants (Alexandra) farm survey results.

The parameters that have been used are in Table 9 with expenses based on the 2005/06 year.

The total farm income from the organic system is estimated to be $\$ 55,570$ more than if Avalon Farming continued to run a conventional system (Table 10). This is an increase in gross income of $\$ 118 /$ ha and $\$ 10.56 / \mathrm{su}$ or $16 \%$ 
Table 10 The income and expenditure from conventional and organic systems on Avalon Farming.

\begin{tabular}{|c|c|c|}
\hline & Conventional $(\$)$ & Organic $(\$)$ \\
\hline \multicolumn{3}{|l|}{ Income } \\
\hline Lamb: Prime & 172500 & 161700 \\
\hline Store & & 42570 \\
\hline Ewes (600 culls) & 21000 & 21000 \\
\hline Wool & 56000 & 70000 \\
\hline Beef: & 40600 & 50400 \\
\hline Total Income & 290100 & 345670 \\
\hline Income/ha & 617 & 735 \\
\hline Income/su & 55.15 & 65.71 \\
\hline \multicolumn{3}{|l|}{ Expenditure $^{1}$} \\
\hline Purchases beef (50) & 25000 & 31000 \\
\hline Animal Health (C \$4/hd; O \$1/hd) & 21000 & 5200 \\
\hline Fertiliser (C $\$ 10 / \mathrm{su} ; 0$ \$5/su) & 52000 & 26000 \\
\hline Feed (C \$4/su; O \$2/su) & 21000 & 10500 \\
\hline Weed and Pest (C \$1.6/su; O \$0.5/su) & 8400 & 2600 \\
\hline Variable expenditure & 127400 & $7 \overline{5} 300$ \\
\hline Other expenses & 159000 & 159000 \\
\hline Total farm working expenses & 286400 & 234300 \\
\hline Expenses/ha & 609 & 498 \\
\hline Expenses/su & 54.44 & 44.54 \\
\hline \multicolumn{3}{|l|}{ Economic farm surplus } \\
\hline Total & 3700 & 111370 \\
\hline Per hectare & 8 & 236 \\
\hline Per stock unit & 0.70 & 21.17 \\
\hline Expenditure as a \% of income & $99 \%$ & $68 \%$ \\
\hline
\end{tabular}

The expenditure on the organic system now running on Avalon Farming is estimated to be $\$ 52,100$ less than if a conventional system was continued (Table 10). This is a saving of $\$ 111 / \mathrm{ha}$ or $\$ 9.90 / \mathrm{su}$, an overall saving of $18 \%$.

This then translates into an increase in economic farm surplus from $\$ 3,700$ to $\$ 111,370$ in the current organic system, with farm expenditure decreasing from $99 \%$ of farm income to $68 \%$ (Table 10).

Table 11 The price paid for lambs sold from organic systems over the past 7 years

\begin{tabular}{lc}
\hline Season & kg CW \\
\hline $1999 / 2000$ & $\$ 6.00+$ pelt \\
$2000 / 01$ & $\$ 5.90+$ pelt \\
$2001 / 02$ & $\$ 5.75+$ pelt \\
$2002 / 03$ & $\$ 5.65+$ pelt \\
$2003 / 04$ & $\$ 5.00+$ pelt \\
$2004 / 05$ & $\$ 5.00+$ pelt \\
$2005 / 06$ & $\$ 4.90$ including pelt \\
\hline
\end{tabular}

\section{Marketing \\ Lamb}

Organic premiums for lamb have been paid by the meat companies since the 1999/2000 season. These premiums have decreased but are still significantly higher than conventional prices. Our lambs are processed by PPCS. They also paid a $10 \%$ premium on transitional year 2 lambs, during the conversion period. Contract price is for the full season and the recent history of prices paid for organic lamb are in Table 11. The average price for the $2005 / 06$ season for a $15 \mathrm{~kg}$ YM carcass produced in a conventional system was $\$ 47.10$ while the price for the same carcass from an organic system was $\$ 73.50$.

\section{Beef}

The North Island export company, Outlands has been paying a premium for organic beef. This was only available in the North Island, but since 2006 they have included the South Island. This premium is variable depending on the time of year, so that they can supply 12 months of the year.

\section{Wool}

Avalon Farming has secured an organic premium for all its wool on a 3 year fixed contract. There are few if any contracts available for organic wool in New Zealand.

\section{Farmers Markets}

We are selling our Avalon Organic branded meat at the Otago Farmers Market every Saturday morning. Approximately 3-4000 people pass through the site at the northern end of the Dunedin Railway Station. Dunedin has the largest farmers market in New Zealand for food products.

This has been a great opportunity to meet the customer 
and sell them your own meat products, something which $99 \%$ of farmers never experience.

A full range of lamb and beef cuts, vacuum packed and branded are sold to the public. We have also used the market to test new products, which we have created, such as gourmet sausages and organic ready-made meals.

\section{Restaurants}

We sell to a small group of top end restaurants in Otago and Southland, who are very happy with the quality and reliability of supply.

\section{Summary}

Organic farming has proven to be an achievable, credible and financially rewarding option at Avalon Farming.

Planning before and during the 2 year conversion period was crucial to a successful transition to organic farming. Changing from a chemical to organic fertiliser program improves the soil biology and has reduced the overall fertiliser requirements of the soil.

Soil fertility and pasture growth rates have been maintained, since starting organic farming 8 years ago.
Stock performance is not significantly lower in an organic system compared to conventional farming. Lambing percentages averaging $6 \%$ less and lamb carcass weights $1 \mathrm{~kg}$ below conventional levels are being achieved. Conventional stock has been farmed under a low input system, which may have limited their potential performance.

The use of worm resistant genetics has allowed the same stocking rate of $11 /$ hectare to be maintained at a sheep to cattle ratio of 90:10. The selling of store lambs into the conventional store market does reduce the overall profitability of organic livestock farming.

Financially, organic farming is out performing the conventional farm. Premiums for lamb, beef and wool from a comparable performance base, have increased income by $16 \%$ over conventional returns. Costs are also reduced by $18 \%$.

Based on the year 2005/06, an estimated economic farm surplus of $\$ 111000$ would be achieved $(\$ 21 /$ su or $\$ 236 /$ hectare), which is well ahead of the conventional area (estimated economic farm surplus $\$ 3700, \$ 0.70 / \mathrm{su}$, $\$ 8 /$ hectare). 